\title{
PERAN PERCEIVED INJUSTICE PADA EVALUASI BIAS TERHADAP OUTGROUP BERDASARKAN PERSPEKTIF DIRI DAN TUHAN
}

\author{
Isnaeni Fajar* \& Mirra Noor Milla \\ Fakultas Psikologi, Universitas Indonesia, Depok \\ *Email: isnaenifajar@ymail.com
}

\begin{abstract}
Abstrak
Kasus penistaan agama pada pilkada DKI tahun 2016 memberikan gambaran bagaimana evaluasi bias dapat terjadi dalam relasi antar kelompok di Indonesia. Selain karena faktor agama, persepsi ketidakadilan dapat menjadi basis evaluasi bias antar kelompok. Kami menduga bahwa perbedaan konteks adil tidak adil memiliki peran terhadap evaluasi bias. Studi eksperimen ini bertujuan untuk mengetahui bagaimana peran persepsi ketidakadilan (vs. adil) terhadap evaluasi bias berdasarkan perspektif diri dan Tuhan ( $N=219$; $M$ age = 21,63; 49\% perempuan). Studi eksperimen ini menggunakan desain 2 (pengambilan perspektif: diri dan Tuhan; within) x 2 (konteks: adil vs. tidak adil; between) mixed design. Evaluasi bias diukur dengan menggunakan skenario pemberian hukuman orang ketiga dimana partisipan memiliki peran sebagai orang ketiga yang dapat memberikan hukuman kepada target outgroup (pemain fiktif). Hasilnya menunjukkan bahwa konteks tidak adil (vs. adil) memiliki perbedaan yang signifikan terhadap evaluasi bias outgroup berdasarkan perspektif diri dan Tuhan. Evaluasi bias akan cenderung untuk lebih tinggi pada konteks tidak adil daripada konteks adil. Hasil ini memiliki implikasi bahwa dalam relasi antar kelompok persepsi ketidakadilan dan penggunaan perspektif diri (vs Tuhan) memiliki pengaruh terhadap evaluasi bias outgroup.
\end{abstract}

Kata kunci: agama, evaluasi bias, konteks, pemberian hukuman

\begin{abstract}
The religious blasphemy case in the 2016 Regional Head election provides an overview of how the evaluation bias can occur in inter-group relations in Indonesia. In addition to religious factors, the perception of injustice could be the basis for evaluation bias between groups. We suspect that unequal fair-context differences have a role to evaluate biases. This experimental study aims to find out how the role of perception of injustice (vs. fair) on the evaluation bias based on self and God's perspective ( $N=219 ; M$ age $=21,63 ; 49 \%$ women). This experimental study uses 2 (perspective taking: self and God, within) $x 2$ (context: fair vs. unjust, between) mixed design. Evaluation bias is measured using a thirdparty punishment scenario where participants have a third person role that can impose punishment on outgroup targets (fictitious players). The results show that the unjust (vs. fair) context has a significant difference to evaluation bias towards outgroup based on self and God's perspective. Moreover, evaluation bias will tend to be higher in an unjust context than a fair context. These results implicate that the perception of injustice and the use of self-perspective (vs God) have an influence on the evaluation bias on towards outgroup in an inter-group relation.
\end{abstract}

Keywords: context, evaluation bias, punishment, religion 


\section{Pendahuluan}

Pada akhir tahun 2016, terjadi demonstrasi yang dilakukan oleh umat Islam untuk menuntut Gubernur DKI Jakarta, Basuki Tjahaja Purnama, diproses secara hukum karena dituduh telah melakukan penistaan agama. Demonstrasi meluas hingga ke daerah kediaman Basuki dan rumah warga keturunan Tionghoa. Sekelompok umat Islam melakukan sweaping disertai perusakan dan penjarahan minimarket milik warga Tionghoa. Secara umum, kasus Basuki ini dapat dijelaskan sebagai sentiment agama dan etnis, karena adanya perilaku permusuhan yang ditunjukkan oleh umat Islam terhadap etnis Tionghoa yang merupakan etnis dari tertuduh. Sikap dan perilaku negatif terhadap kelompok yang berbeda ini disebut dengan evaluasi bias (Hewstone, Rubin, \& Wilis, 2002).

Studi terdahulu mengenai evaluasi bias membuktikan bahwa evaluasi bias antar kelompok dapat terjadi karena identifikasi diri pada kelompok kita (ingroup) yang tinggi (Perdue, Dovidio, Gurtman, \& Tyler, 1990), kategorisasi diri (Leonardelli \& Brewer, 2001), need for cognitive closure yang tinggi (Shah, Kruglanski, \& Thompson, 1998), orientasi dominansi sosial yang tinggi (Sidanius, Levin, Liu, \& Pratto, 2000), dan pengalaman multikultural (Tadmor, Hong, Chao, Wiruchnipawan, \& Wang, 2012). Masih terbatas studi evaluasi bias antar kelompok yang menjelaskan peran agama, seperti dalam kasus penistaan agama. Oleh karena itu, studi ini akan melihat bagaimana peranan agama dalam menjelaskan evaluasi bias antar kelompok.

Penjelasan evaluasi bias dilakukan antar kelompok berbasis agama, telah dijelaskan oleh Brandt dan Van Tongeren (2017), dimana evaluasi dari satu kelompok ke kelompok lain (outgroup) akan negatif, terutama kepada kelompok yang memiliki ajaran agama yang berbeda. Evaluasi bias terhadap kelompok lain ini juga dapat meningkat, prasangka dan juga intensi kekerasan, khususnya pada kondisi kelompok lain dipersepsi tidak adil dan telah melakukan pelanggaran moral (Blogowska, Saroglou, \& Lambert, 2013). Individu beragama akan sensitif terhadap isu moral dan norma agama, yang akan mengakibatkan diskriminasi dan prasangka terhadap kelompok lain yang dipersepsi telah melakukan pelanggaran moral atau dapat mengancam nilai keagamaan kelompok kita (Rowatt, Carpenter, \& Haggard, 2013). Perilaku terhadap kelompok lain yang dianggap sebagai pelanggar moral ini adalah agresif, diskriminatif, atau mengutamakan kelompoknya pada perilaku prososial (Blogowska, dkk., 2013).

Tidak hanya kelompok yang berbasis agama, evaluasi bias juga terjadi pada kelompok berbasis ras dan etnis, dimana prasangka juga akan meningkat terhadap outgroup ras yang berbeda (Johnson, Rowatt, \& Labouff, 2010). Selain agama dan etnis, perbedaan konteks menjadi faktor penting dalam mempengaruhi evaluasi bias antar kelompok. Studi dari Ginges, Sheikh, Atran, dan Argo (2016) menunjukkan bahwa evaluasi bias dapat dipengaruhi oleh konteks. Ginges, dkk. (2016) menjelaskan dalam konteks konflik di wilayah Gaza, ia menunjukkan bahwa evaluasi bias lebih tinggi dibandingkan dengan partisipan di wilayah West Bank, yang merupakan daerah non-konflik. Untuk menjelaskan dinamika evaluasi bias dalam penistaan agama seperti yang terjadi di Indonesia, konteks diprediksi memiliki peranan yang penting terhadap evaluasi bias. Selain konteks konflik vs non konflik, persepsi adil dan tidak adil, serta afiliasi kelompok berbasis agama dan etnis, diprediksi dapat mempengaruhi evaluasi bias dalam kasus penistaan agama di Indonesia yang akan diperiksa lebih lanjut dalam studi ini.

Oleh karena itu, penelitian ini dilakukan untuk mengetahui bagaimana perbedaan peran konteks tidak adil (vs. adil) terhadap evaluasi bias dari perspektif diri dan Tuhan. Perspektif diri dan Tuhan dalam penilaian evaluasi bias 
dinilai relevan untuk memprediksi evaluasi terhadap kelompok outgroup yang berbasis agama, disebabkan orang beragama seringkali menggunakan teks sebagai representasi perintah Tuhan yang digunakan sebagai dasar perilaku. Evaluasi bias diukur dengan menggunakan pemberian hukuman orang ketiga yang diadaptasi dari Schiller, Baumgartner, dan Knoch (2014). Partisipan akan berperan sebagai orang ketiga yang dapat menghukum outgroup dalam yang bermain tidak adil (vs. adil) terhadap ingroup di skenario Prisoner's Dilemma Game. Kemudian partisipan akan merespon pemberian hukuman orang ketiga ini dari perspektif diri dan Tuhan.

\section{Evaluasi Bias antar Kelompok.}

Evaluasi bias merupakan sikap dan perilaku negatif seseorang terhadap kelompok lain yang diluar dari kelompoknya (Hewstone, dkk., 2002). Menurut teori identitas sosial, individu akan menggunakan keanggotaan dalam kelompok untuk mempertahankan dan meningkatkan kepercayaan diri (selfesteem) mereka (Tajfel \& Turner, 2001). Evaluasi bias ini dapat terjadi karena adanya perbedaan ajaran agama antar kelompok (Brandt \& Van Tongeren, 2017), identifikasi diri pada kelompok kita (Perdue, dkk., 1990), kategorisasi diri (Leonardelli \& Brewer, 2001), need for cognitive closure (Shah, dkk., 1998), orientasi dominansi sosial (Sidanius, dkk., 2000), pengalaman multikultural (Tadmor, dkk., 2012), dan pengambilan perspektif (Ginges, dkk., 2016).

Evaluasi bias dapat dijelaskan dari kebutuhan mengevaluasi diri secara positif sebagai bagian dari anggota kelompok. Dalam proses untuk mempertahankan kepercayaan diri yang positif, individu akan melakukan perbandingan antara ingroup dengan outgroup. Ketika individu merasa tidak puas, mereka akan berusaha untuk meninggalkan kelompok mereka dan bergabung pada kelompok yang lebih kuat, atau membuat kelompok mereka lebih positif dibandingkan kelompok lainnya (Tajfel \& Turner, 2001).
Kompetisi untuk membuat kelompok sendiri lebih kuat dan mempertahankan kepercayaan diri individu pada dua kelompok yang berbeda mengakibatkan bias terhadap kelompok lain yang berbeda dari kelompoknya. Kemudian individu itu akan melihat outgroup lebih rendah dari kelompok mereka sendiri, yang kemudian dapat memberikan perlakuan negatif pada outgroup.

Disisi lain, evaluasi bias terhadap kelompok lain, pada kelompok berbasis agama bekerja secara khas dalam menjelaskan hubungan antar kelompok melalui prasangka dan potensi kekerasan terhadap anggota outgroup, khususnya terhadap para pelanggar moral (Blogowska, dkk., 2013). Sehingga untuk menjelaskan kasus Basuki yang merupakan pelanggar moral, faktor agama diprediksi memiliki peran yang penting terhadap evaluasi bias.

Untuk menjelaskan bagaimana pengaruh agama terhadap evaluasi bias, Galen (2012) menyebutkan dua alasan. Pertama, hal ini dapat terjadi karena agama merupakan basis identitas sosial yang kuat sehingga ketika individu diminta untuk memberikan penilaian kepada orang lain dengan basis agama, mereka akan cenderung untuk mengutamakan individu yang beragama sama dibandingkan individu yang tidak beragama maupun yang memiliki agama berbeda (Galen, 2012; Rowatt, Franklin, \& Cotton, 2005). Kedua adalah stereotipe moral. Individu beragama akan memiliki stereotipe moral untuk menilai apakah seorang bermoral atau tidak. Contohnya adalah individu Muslim akan cenderung memiliki sikap lebih positif pada orang yang menggunakan atribut agama mereka, seperti penggunaan jilbab, dibandingkan dengan orang yang tidak menggunakan jilbab, dan mereka akan menganggap orang yang menggunakan atribut agama sebagai orang yang bermoral (Chia \& Jih, 1994). Dari pemaparan tersebut, dapat dikatakan bahwa agama merupakan prediktor kuat terhadap evaluasi bias antar kelompok. 
Berpikir Menggunakan Sudut Pandang Tuhan. Individu memiliki kemampuan untuk merepresentasikan pikiran lain dan konten pemikirannya, khususnya pada objek yang memiliki pemikiran tersendiri, dan kemampuan untuk merepresentasikan pikiran dari objek lain ini disebut dengan persepsi pikiran atau yang dalam istilah Gervais (2013) disebut persepsi pikiran. Lazimnya, kemampuan persepsi pikiran ini digunakan untuk merepresentasikan pikiran individu lain dan menggunakan sudut pandang individu tersebut, namun persepsi pikiran pun dapat digunakan terhadap agen supernatural seperti Tuhan.

Menurut Gervais (2013), apabila Tuhan memiliki pemikiran tersendiri, maka manusia yang memiliki kemampuan dan mekanisme kognitif yang dapat merepresentasikan pemikiran orang lain dapat mempersepsikan dan berpikir dari sudut pandang Tuhan, seperti bagaimana individu mempersepsikan pemikiran individu lainnya. Hal ini ditunjukkan secara jelas pada saat individu berdoa kepada Tuhan. Berdoa merupakan cara komunikasi manusia dengan Tuhan, dimana pada saat berdoa bagian otak temporoparietal, temporopolar, anteromedial prefrontal cortex, dan precuneus menjadi aktif dan bagian tersebut merupakan bagian otak yang sama yang diidentifikasi aktif dengan persepsi pikiran (Schjoedt, Stødkilde-Jorgensen, Geertz, \& Roepstorff, 2009).

Studi terdahulu menunjukkan bahwa individu dari agama tertentu cenderung memberikan evaluasi dan stereotipe negatif terhadap individu dari agama lain (Harper, 2007). Akan tetapi dalam dinamika perspektif Tuhan dan evaluasi bias, hasil ini akan berbeda apabila seseorang menggunakan perspektif Tuhan ketika menilai kelompok lain. Preston dan Ritter (2013) membuktikan bahwa dengan memberikan priming agama kepada seseorang hanya dapat meningkatkan perilaku menolong pada anggota kelompoknya saja. Sementara memberikan priming Tuhan dan konsep
Tuhan yang lebih universal dalam diri seseorang justru dapat meningkatkan perilaku menolong pada anggota outgroup (Preston \& Ritter, 2013; Shariff \& Norenzayan, 2007).

Selain itu, perspektif Tuhan dianggap memiliki nilai-nilai universal. Hal ini dapat dijelaskan ketika Tuhan menganjurkan bagi umatNya untuk berbuat baik bagi semua manusia tanpa memandang suku, agama, ras, dan antargolongan maka umat beragama akan cenderung berbuat hal yang sama (Preston \& Ritter, 2013). Dalam hal ini, studi Ginges, dkk. (2016) membuktikan bahwa berpikir dengan menggunakan perspektif Tuhan dapat menurunkan evaluasi bias pada kelompok lain dibandingkan dengan menggunakan perspektif diri.

Persepsi Ketidakadilan. Evaluasi bias terbukti dapat dipengaruhi oleh faktor konteks yang berbeda (Ginges, dkk., 2016). Lebih lanjut, dalam dinamika evaluasi bias antar kelompok beragama, konteks ketidakadilan memiliki peranan yang penting dimana seseorang akan cenderung untuk memiliki sikap dan pandangan yang negatif pada kelompok lain, khususnya ketika kelompok lain melakukan ketidakadilan atau melanggar moral kelompok kita (Rowatt, dkk., 2013; Blogowska, dkk., 2013). Oleh karena itu, konteks tidak adil (vs. adil) menjadi variabel terikat kedua yang dapat mempengaruhi evaluasi bias antar kelompok beragama.

Schiller, dkk. (2014) menjelaskan bahwa evaluasi bias dapat diukur dengan menggunakan skenario pemberian hukuman orang ketiga. Apabila pemain ingroup dihukum lebih kecil oleh partisipan dibandingkan dengan outgroup maka hal ini mengindikasikan ingroup favoritism. Sedangkan apabila outgroup dihukum lebih tinggi dibandingkan dengan ingroup maka hal ini mengindikasikan diskriminasi outgroup. Hal ini dapat terjadi karena ketika seseorang memberikan hukuman kepada orang lain, ia akan cenderung untuk tidak objektif. Artinya, orang tersebut akan cenderung untuk memberikan 
hukuman yang lebih besar pada kelompok lain dibandingkan dengan kelompoknya sendiri, atau ia akan memberikan hukuman yang lebih besar pada kelompok lain yang melakukan pelanggaran moral dibandingkan dengan apabila kelompoknya yang melakukan pelanggaran moral (Schiller, dkk., 2014).

Dalam skenario pemberian hukuman orang ketiga, seseorang akan memiliki peran sebagai orang ketiga yang dapat memberikan hukuman kepada salah satu pemain fiktif yang melakukan ketidakadilan (vs. adil) terhadap lawan main pemain fiktif tersebut. Pengukuran ini efektif untuk mengukur evaluasi bias karena pemberian hukuman dalam skenario pemberian hukuman orang ketiga terbukti terjadi karena individu mengutamakan kelompoknya dan adanya diskriminasi pada kelompok lain.

Sementara itu, konteks dimana salah satu pemain akan melakukan perilaku curang (tidak adil) atau keduanya saling bekerjasama (adil) dalam skenario pemberian hukuman orang ketiga merupakan hal yang penting di skenario pemberian hukuman orang ketiga. Pada konteks tidak adil, orang ketiga akan cenderung untuk memberikan hukuman kepada pelaku yang melakukan kecurangan karena motif menghukum orang yang melakukan kesalahan (Schiller, dkk., 2014). Evaluasi bias pada konteks tidak adil akan muncul apabila orang ketiga menghukum pelaku dengan nilai hukuman yang lebih rendah atau lebih tinggi dibandingkan dengan orang lain.

Di sisi lain, pada konteks adil, orang ketiga seharusnya akan cenderung untuk tidak memberikan hukuman kepada salah satu pemain fiktif yang bermain Prisoner's Dilemma Game (PDG). Akan tetapi, apabila orang ketiga tetap memberikan hukuman kepada outgroup di konteks adil, maka orang ketiga tersebut menunjukkan diskriminasi outgroup (Goette \& Meier, 2011).

\section{Metode Penelitian}

Partisipan. Pada awalnya partisipan berjumlah 240 orang yang direkrut di Universitas Indonesia. Akan tetapi, terdapat beberapa partisipan yang beragama nonMuslim, tidak memenuhi kriteria usia dari penelitian, dan tidak menjawab pertanyaan dari skenario pemberian hukuman ketiga. Sehingga total partisipan yang digunakan dalam penelitian ini berjumlah 219 orang (47\% perempuan, $M$ age $=21,63, S D=$ 1,674).

Partisipan direkrut dengan cara purposive sampling berdasarkan kriteria yang digunakan dalam studi ini, yaitu berumur 20 - 26 tahun, beragama Islam, dan memiliki kewarganegaraan Indonesia. Kriteria ini digunakan karena pada individu yang berumur di bawah 20 tahun, mereka akan cenderung memiliki pandangan terkait Tuhan yang dipengaruhi oleh orang tua mereka (Potvin, 1977), dan dikhawatirkan dapat mengganggu respon jawaban dari perspektif Tuhan. Selain itu, kriteria Muslim dan berkewarganegaraan Indonesia bertujuan untuk mengetahui bagaimana evaluasi bias yang terjadi pada orang Muslim dan Pribumi.

Variabel Penelitian. Variabel terikat dari penelitian ini adalah evaluasi bias dimana partisipan berperan sebagai orang ketiga yang dapat memberikan hukuman kepada pemain fiktif di skenario PDG dengan jarak hukuman antara 0 25. Hukuman yang diberikan oleh partisipan mengindikasikan evaluasi bias mereka terhadap kelompok lain. Sementara itu, terdapat dua variabel bebas pada penelitian ini. Pertama adalah pengambilan perspektif dimana partisipan akan merespon pertanyaan skenario pemberian hukuman orang ketiga dari perspektif diri (dan Tuhan). Variabel bebas kedua adalah persepsi ketidakadilan yang dimanipulasi dengan menggunakan skenario adil vs tidak adil. Dalam skenario ini partisipan akan merespon hukuman dari konteks yang berbeda, yaitu adil (vs. tidak adil).

Desain. Dua (pengambilan perspektif: diri dan Tuhan; within) x dua (skenario: tidak adil vs. adil; between) mixed design. Dalam penelitian ini, ada dua kelompok eksperimen dengan desain penelitian mixed desain dimana pengambilan pespektif sebagai variabel within. 
Instrumen dan Material Penelitian. Manipulasi variabel independen: Pemberian hukuman orang ketiga. Partisipan pada pemberian hukuman orang ketiga akan berperan sebagai orang ketiga yang dapat menghukum salah satu pemain fiktif dalam skenario PDG. Pemain fiktif, yaitu pemain $A$ dan pemain $B$, akan memiliki 50 poin yang dapat mereka berikan kepada lawan main mereka atau tidak. Setiap poin yang pemain fiktif tersebut berikan akan dikalikan dua. Apabila kedua pemain tersebut bekerja sama dan saling memberikan poin mereka maka masing-masing pemain akan mendapatkan total 100 poin (adil). Akan tetapi, apabila salah satu pemain memilih untuk tidak bekerja sama maka salah satu pemain akan mendapatkan nilai 150, dan pemain lawannya akan mendapatkan nilai 0 (tidak adil).

Semua partisipan menjadi pemain $\mathrm{C}$ yang akan memberikan hukuman ke pemain A. Partisipan diberikan 25 poin yang dapat digunakan untuk menghukum pemain A. Setiap poin yang digunakan untuk menghukum pemain $A$ akan dikalikan dua, sehingga apabila partisipan menghukum pemain $A$ dengan poin 25 maka poin pemain A akan dikurangi 50 .

Skenario. Pada manipulasi skenario, peneliti memberikan dua skenario yang berbeda pada pemberian hukuman orang ketiga, yaitu skenario adil dan tidak adil. Di skenario adil partisipan diberikan konteks dimana pemain fiktif A (outgroup) bekerja sama dengan pemain fiktif $B$ (ingroup) dengan cara masing-masing pemain fiktif memberikan poin mereka ke lawan mainnya sehingga kedua pemain tersebut mendapatkan hasil maksimal dan sama rata. Sedangkan pada manipulasi skenario tidak adil, partisipan diberikan konteks dimana pemain fiktif $A$ (outgroup) memilih untuk tidak bekerja sama dengan pemain fiktif B (ingroup) dengan cara tidak memberikan poin ke pemain fiktif $B$ (ingroup) sehingga pemain fiktif A (outgroup) mendapatkan hasil maksimal, namun pemain fiktif (ingroup) mendapatkan hasil nol.
Prosedur. Peneliti akan memberikan cover story bahwa peneliti ingin mengetahui respon masyarakat dalam memberikan hukuman pada situasi yang adil maupun tidak adil. Apabila partisipan bersedia untuk mengikuti penelitian, mereka akan diberikan pulpen beserta lembar penelitian.

Lembar penelitian akan memiliki beberapa bagian. Bagian pertama merupakan data identitas dari partisipan, dan kesediaan mereka untuk mengikuti penelitian ini. Identitas partisipan mencakup jenis kelamin, umur, suku, dan agama. Kemudian, partisipan akan membaca skenario pemberian hukuman orang ketiga dimana mereka akan diberikan teks bahwa terdapat dua orang yang sedang bermain sebuah permainan dimana masing-masing pemain memiliki poin sebesar 50 .

Kemudian, partisipan diberikan permasalahan dalam skenario ini dimana terdapat salah satu pemain, yaitu pemain A yang memiliki identitas outgroup, memilih untuk tidak bekerjasama dengan pemain $B$ yang dimana merupakan anggota ingroup dari partisipan (vs. kedua pemain memilih untuk bekerjasama). Berikutnya, partisipan diberikan 25 poin, dan pilihan untuk menghukum pemain $A$ dengan rentang $0-25$, terlepas dari pemain $A$ tersebut memilih untuk bekerjasama atau tidak.

Perlu diketahui bahwa kedua pemain memiliki pilihan untuk bekerjasama dengan cara memberikan poin yang mereka miliki dan mendapatkan hasil dua kali lipat, atau tidak bekerjasama dengan cara tidak memberikan poin kepada pemain lain dan hanya mendapatkan poin yang mereka miliki saat itu saja. Apabila kedua pemain bekerjasama maka poin yang mereka miliki akan dikali 2 sehingga masingmasing pemain akan mendapatkan poin sebesar 100. Namun, apabila salah satu pemain memilih untuk tidak bekerjasama, maka salah satu pemain akan mendapatkan poin sebesar 150 , dan pemain lainnya tidak mendapatkan poin apapun.

Setelah itu, partisipan diberikan pertanyaan untuk merespon skenario 
tersebut dari sudut pandang diri mereka terlebih dahulu dan kemudian dari sudut pandang Tuhan. Pertanyaan dari sudut pandang diri adalah: "Menurut Anda, seberapa besar hukuman yang pantas Anda berikan?" dan dari sudut pandang Tuhan adalah: "Menurut Anda, seberapa besar hukuman yang akan diperkenankan oleh Allah?" Kemudian untuk mengukur evaluasi bias yang terjadi, mengukur jumlah poin hukuman yang diberikan oleh partisipan.

Setelah partisipan selesai mengisi semua lembar penelitian tersebut, peneliti akan memberikan debriefing kepada partisipan untuk memberitahu tujuan dari penelitian ini, dan dapat mengajukan pertanyaan apabila ada yang ingin mereka ketahui terkait penelitian ini. Partisipan diberikan minuman kemasan sebagai hadiah atas keikutsertaan dari partisipan. Estimasi waktu dalam proses pengisian lembar jawaban diasumsikan akan berlangsung selama 15 - 20 menit.

Analisis Statistik. Independent-sample t-test digunakan untuk membandingkan evaluasi bias dari perspektif diri dan Tuhan pada skenario tidak adil dan adil. Pada analisis pertama, evaluasi bias dari perspektif diri akan menjadi variabel terikat studi ini, dan kedua skenario adil dan tidak adil sebagai variabel bebas. Begitu juga dengan analisis kedua, skenario adil dan tidak adil sebagai variabel bebas, sedangkan variabel terikatnya adalah evaluasi bias dari perspektif Tuhan. Selain itu, kami juga melakukan analisis paired-sample t-test untuk membandingkan evaluasi bias dari perspektif diri dan evaluasi bias dari perspektif Tuhan.

\section{Hasil Penelitian}

Hasil analisis deskriptif menunjukkan bahwa pada skenario tidak adil, evaluasi bias dari perspektif diri memiliki mean sebesar 12,94, sedangkan evaluasi bias dari perspektif Tuhan memiliki mean sebesar 11,58 . Sebaliknya, pada skenario adil, evaluasi bias dari perspektif diri memiliki mean sebesar 5,90, sedangkan evaluasi bias dari perspektif Tuhan memiliki mean sebesar 6,86 .

Hasil analisis independent t-test menunjukkan bahwa terdapat perbedaan yang signifikan antara skenario tidak adil vs adil terhadap evaluasi bias dari perspektif diri $(t(217)=6,211 ; p<0,01)$. Khususnya, partisipan cenderung menunjukkan evaluasi bias dari perspektif diri yang lebih tinggi pada skenario tidak adil ( $M=$ 12,94; $S E=0,798$ ) daripada skenario adil $(M=5,90 ; S E=0,803)$.

Selain itu, hasil analisis independent t-test juga menunjukkan bahwa terdapat perbedaan yang signifikan antara skenario tidak adil dan adil terhadap evaluasi bias dari perspektif Tuhan $(t(217)=3,468$; $p<$ $0,01)$. Partisipan menunjukkan evaluasi bias dari perspektif Tuhan yang lebih tinggi pada skenario tidak adil $(M=11,58$; $S E=1,011)$ daripada skenario adil $(M=$ 6,86; $S E=0,913)$. Hasil analisis pairedsample t-test menunjukkan bahwa tidak terdapat perbedaan yang signifikan antara evaluasi bias dari perspektif diri dan Tuhan $(\mathrm{t}(218)=0,244 ; \mathrm{p}>0,05)$. Dengan kata lain, partisipan memiliki evaluasi bias yang relatif sama ketika menggunakan perspektif diri $(M=9,37$, $S E=0,613)$ dan $\operatorname{Tuhan}(M=9,19 ; S E=$ $0,697)$.

Tabel 1. Rata-rata evaluasi bias dari perspektif diri dan Tuhan berdasarkan pada skenario tidak adil vs adil

\begin{tabular}{|c|c|c|c|c|c|}
\hline & \multirow{2}{*}{$\begin{array}{l}\text { Skena } \\
\text { rio }\end{array}$} & \multicolumn{2}{|c|}{$\begin{array}{c}\text { Evaluasi bias dari perspektif } \\
\text { diri }\end{array}$} & \multicolumn{2}{|c|}{$\begin{array}{l}\text { Evaluasi bias dari perspektif } \\
\text { Tuhan }\end{array}$} \\
\hline & & Mean & SE & Mean & SE \\
\hline \multirow{2}{*}{ Adil } & Tidak & 12,94 & 0,798 & 11,58 & 1,011 \\
\hline & Adil & 5,90 & 0,803 & 6,86 & 0,913 \\
\hline
\end{tabular}




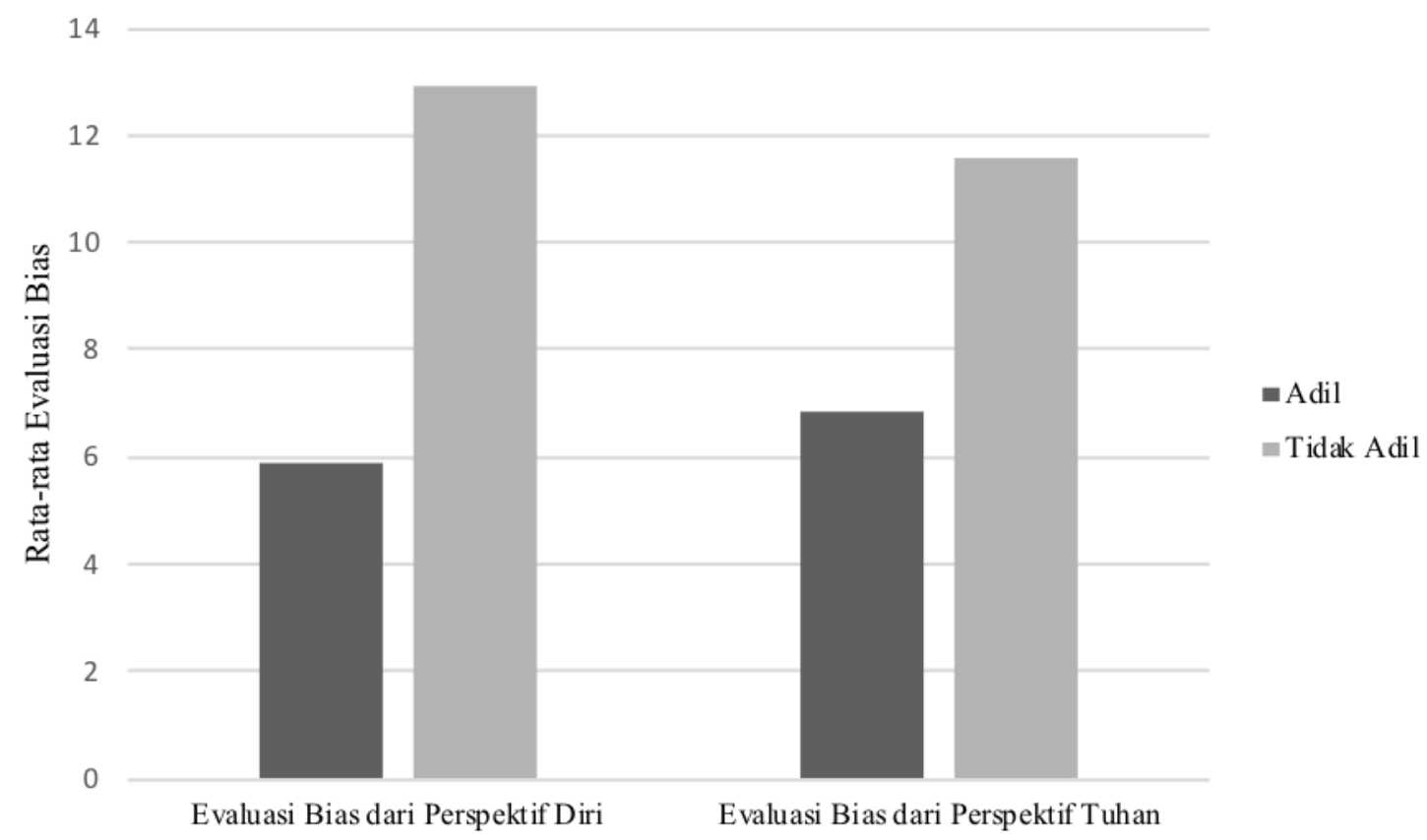

\section{Grafik 1. Evaluasi bias dari perspektif diri dan Tuhan pada konteks adil dan tidak adil.}

\section{Diskusi}

Terdapat dua temuan penting dalam studi ini. Pertama, tidak ditemukan perbedaan evaluasi bias pada penggunaan perspektif diri dan Tuhan. Kedua, evaluasi bias berdasarkan penggunaan perspektif menunjukkan perbedaan yang signifikan pada skenario tidak adil dan adil. Evaluasi bias terhadap outgroup lebih tinggi pada kondisi dimana terdapat persepsi ketidakadilan dibandingkan pada saat dipersepsi adil. Sesuai dengan studi terdahulu, temuan dalam studi ini menunjukkan bahwa evaluasi bias, khususnya pemberian hukuman, akan lebih tinggi terhadap kelompok lain pada konteks tidak adil daripada adil (McKay, Efferson, Whitehouse, \& Fehr, 2010).

Berbeda pada konteks tidak adil, dalam konteks adil individu akan cenderung tidak memberikan hukuman kepada kelompok lain ataupun kelompoknya, karena tidak adanya motif ganjaran, yang menjadi motif utama dari pemberian hukuman kepada individu lain (Carlsmith, 2006). Motif ganjaran ini yang menyebabkan adanya evaluasi bias, yaitu mengutamakan kelompoknya dan diskriminasi kelompok lain, dalam pemberian hukuman (Schiller, dkk., 2014). Hal ini disebabkan karena persepsi ketidakadilan yang diterima menyebabkan individu cenderung untuk menghukum kelompok lain dengan lebih tinggi (Schiller, dkk., 2014). Pada konteks tidak adil, individu akan cenderung untuk menghukum kelompok lain lebih tinggi karena ia cenderung tidak bersedia mencoba untuk memahami kelompok lain. Berbeda dengan relasi individu dengan kelompoknya sendiri, dimana ia akan berusaha untuk memahami dan menjustifikasi perilaku tidak adil atau pelanggaran yang dilakukan oleh kelompoknya (Baumgartner, Götte, Gügler, \& Fehr, 2012).

Temuan ini menjadi menarik karena apabila Tuhan dapat meningkatkan perilaku memaafkan dan menolong outgroup, beserta mengurangi evaluasi bias (Preston \& Ritter, 2013; Ginges, dkk., 2016), maka seharusnya evaluasi bias dari perspektif Tuhan tidak memiliki perbedaan yang signifikan pada kondisi saat dipersepsi tidak adil maupun adil. Akan tetapi, perbedaan evaluasi bias dari perspektif 
Tuhan pada saat dipersepsi tidak adil dan adil ini mungkin terjadi disebabkan seseorang akan memiliki evaluasi bias yang lebih tinggi terhadap outgroup khususnya apabila mereka dinilai telah melakukan pelanggaran moral (Rowatt, dkk., 2013).

Sementara perbedaan evaluasi bias justru tidak ditemukan pada penggunaan perspektif diri dan Tuhan. Hal ini mengindikasikan evaluasi bias seseorang ketika menggunakan perspektif diri relatif sama dengan ketika ia menggunakan perspektif Tuhan. Hal ini dapat menjelaskan bahwa konteks ketidakadilan memiliki peran penting dalam dinamika hubungan antar kelompok yang berbasis agama dan penilaian evaluasi bias. Seseorang tetap akan memiliki evaluasi bias terhadap individu atau kelompok lain yang melakukan pelanggaran dari sudut pandang diri maupun Tuhan pada saat terdapat persepsi ketidakadilan. Dengan kata lain, evaluasi bias dari perspektif diri dapat terjadi karena adanya motif ganjaran (Schiller, dkk., 2014), dan evaluasi bias dari perspektif Tuhan dapat terjadi karena adanya motif keadilan (Mckay, dkk., 2010). Studi ini menunjukkan bahwa selain konteks konflik yang dapat menjelaskan evaluasi bias pada outgroup, konteks ketidakadilan juga memiliki peran penting dalam menjelaskan evaluasi bias outgroup, khususnya pada relasi antar kelompok yang berbasis agama dan menggunakan penilaian moral.

Limitasi dan Saran. Dalam penelitian ini tidak ada kelompok kontrol, kelompok dibagi berdasarkan perlakuan yang berbeda dan dibandingkan. Selain itu, dalam penelitian ini tidak dilakukan perbandingan kelompok target berdasarkan ingroup-outgroup. Hal ini mengakibatkan peneliti tidak dapat mengukur dan membandingkan target kelompok lain dengan kelompok dari partisipan itu sendiri. Oleh karena itu, saran untuk penelitian selanjutnya dapat memasukkan kelompok ingroup sebagai kelompok target untuk membandingkan evaluasi bias ingroup dan outgroup.

\section{Kesimpulan}

Studi ini menemukan dua hal dalam menjelaskan evaluasi bias terhadap outgroup. Pertama, tidak terdapat perbedaan evaluasi bias terhadap outgroup pada saat menggunakan persepsi diri maupun persepsi Tuhan. Baik menggunakan perspektif diri maupun perspektif Tuhan, evaluasi bias terhadap outgroup cenderung sama. Kedua, perbedaan ditemukan pada saat terdapat persepsi ketidakadilan terhadap outgroup. Persepsi ketidakadilan mempengaruhi evaluasi bias terhadap outgroup baik menggunakan perspektif diri maupun perspektif Tuhan. Dimana dalam kondisi terdapat persepsi ketidakadilan, evaluasi bias terhadap outgroup sama-sama lebih tinggi dibandingkan pada saat outgroup dipersepsi adil, baik dengan menggunakan perspektif diri maupun Tuhan.

Hasil ini semakin memperkuat studi terdahulu bahwa dalam konteks tidak adil seseorang akan memiliki evaluasi bias yang lebih tinggi terhadap kelompok lain. Khususnya, baik ketika seseorang menggunakan perspektif diri maupun Tuhan, mereka akan mempunyai evaluasi bias yang tinggi terhadap kelompok lain ketika berada dalam konteks tidak adil dibandingkan dengan konteks adil.

\section{Daftar Pustaka}

Baumgartner, T., Götte, L., Gügler, R. and Fehr, E. (2012). The mentalizing network orchestrates the impact of parochial altruism on social norm enforcement. Hum. Brain Mapp., 33, 1452-1469. doi: 10.1002/hbm.21298

Blogowska, J., Lambert, C., \& Saroglou, V. (2013). Religious prosociality and aggression: It's real. Journal for the Scientific Study of Religion, 52(3), 524-536. doi: 10.1111/jssr.12048

Brandt, M. J., \& Van Tongeren, D. R. (2017). People both high and low on religious fundamentalism are prejudiced toward dissimilar groups. Journal of Personality and Social 
Psychology, 112(1), 76-97. doi: 10.1037/pspp0000076

Carlsmith, K. M. (2006). The roles of retribution and utility in determining punishment. Journal of Experimental Social Psychology, 42(4), 437-451. doi: 10.1016/j.jesp.2005.06.007

Chia, E. K., \& Jih, C. S. (1994). The effects of stereotyping on impression formation: Cross-cultural perspectives on viewing religious persons. The Journal of Psychology, 128(5), 559-565. doi: 10.1080/00223980.1994.9914913

Galen, L. W. (2012). Does religious belief promote prosociality? A critical examination. Psychological Bulletin, 138(5), 876-906. doi: 10.1037/a0028251

Gervais, W. M. (2013). Perceiving minds and gods: How mind perception enables, constrains, and is triggered by belief in gods. Perspectives on Psychological Science, 8(4), 380394. doi: $10.1177 / 1745691613489836$

Ginges, J., Sheikh, H., Atran, S., \& Argo, N. (2016). Thinking from God's perspective decreases biased valuation of the life of a nonbeliever. Proceedings of the National Academy of Sciences, 113(2), 316319. doi: 10.1073/pnas.1512120113

Goette, L., \& Meier, S. (2011). Can integration tame conflicts? Science, 334(6061), 1356-1357. doi: $10.1126 /$ science. 1215617

Harper, M. (2007). The stereotyping of nonreligious people by religious student: Contents and subtypes. Journal for the Scientific Study of Religion, 46(4), 539-552. doi: 10.1111/j.1468-5906.2007.00376.x

Hewstone, M., Rubin, M., \& Willis, $H$. (2002). Intergroup bias. Annual Review of Psychology, 53, 575-604. doi: 10.1146/annurev.psych.53.100901. 135109

Johnson, M. K., Rowatt, W. C., \& LaBouff, J. (2010). Priming Christian religious concepts increases racial prejudice. Social Psychological and Personality Science, 1, 119-126. doi: $10.1177 / 1948550609357246$
Leonardelli, G. J., \& Brewer, M. B. (2001). Minority and majority discrimination: When and why. Joumal of Experimental Social Psychology, 37, 468-485. doi: 10.1006/jesp.2001.1475

McKay, R., Efferson, C., Whitehouse, H., \& Fehr, E. (2010). Wrath of God: Religious primes and punishment. Proceedings of the Royal Society $B, 278,1858-1863$. doi: 10.1098/rspb.2010.2125

Perdue, C. W., Dovidio, J. F., Gurtman, M. B., \& Tyler, R. B. (1990). Us and them: Social categorization and the process of intergroup bias. Journal of Personality and Social Psychology, 59(3), 475-486. doi: 10.1037/0022-3514.59.3.475

Potvin, R. H. (1977). Adolescent God images. Review of Religious Research, 19(1), 43-53. doi: 10.2307/3509579

Preston, J. L., \& Ritter, R. S. (2013). Different effects of religion and God on prosociality with the ingroup and outgroup. Personality and Social Psychology Bulletin, 39(11), 1471-1483. doi: 10.1177/0146167213499937

Rowatt, W. C., Carpenter, T., \& Haggard, M. (2013). Religion, prejudice and intergroup relations. In V. Saroglou (Ed.), Religion, Personality, and Social Behavior (pp. 170-192). New York: Psychology Press

Rowatt, W. C., Franklin, L. M., \& Cotton, M. (2005). Patterns and personality correlates of implicit and explicit attitudes toward Christians and Muslims. Journal for the Scientific Study of Religion, 44(1), 29-43. doi: 10.1111/j.1468-5906.2005.00263.x

Schiller, B., Baumgartner, T., \& Knoch, D. (2014). Intergroup bias in third-party punishment stems from both ingroup favoritism and outgroup discrimination. Evolution and Human Behavior, 35(3), 169-175. doi: 10.1016/j.evolhumbehav.2013.12.006

Schjoedt, U., Stødkilde-Jørgensen, H., Geertz, A. W., \& Roepstorff, A. (2009). Highly religious participants recruit areas of social cognition in 
personal prayer. Social Cognitive and Affective Neuroscience, 4(2), 199-207. doi: 10.1093/scan/nsn050

Shah, J. Y., Kruglanski, A. W., \& Thompson, E. P. (1998). Membership has its (epistemic) rewards: Need for closure effects on in-group bias. Journal of Personality and Social Psychology, 75(2), 383-393. doi: 10.1037/0022-3514.75.2.383

Shariff, A. F., \& Norenzayan, A. (2007). God is watching you: Priming God concepts increases prosocial behavior in an anonymous economic game. Psychological Science, 18(9), 803-809. doi: 10.1111/j.1467-9280.2007.01983.x

Sidanius, J., Levin, S., Liu, J., \& Pratto, F. (2000). Social dominance orientation, anti-egalitarianism and the political psychology of gender: An extension and cross-cultural replication. European Journal of Social Psychology, 30, 41-67. doi: 10.1002/(SICI)10990992(200001/02)30:1<41::AIDEJSP976>3.0.CO;2-O

Tadmor, C. T., Hong, Y. Y., Chao, M. M., Wiruchnipawan, F., \& Wang, W. (2012). Multicultural experiences reduce intergroup bias through epistemic unfreezing. Journal of Personality and Social Psychology, 103(5), 750. doi: 10.1037/a0029719

Tajfel, H., \& Turner, J. C. (2001). An integrative theory of intergroup conflict. In M. A. Hogg \& D. Abrams (Eds.), Key readings in social psychology. Intergroup relations: Essential readings (pp. 94-109). New York: Psychology Press 